\title{
Introdução: da genética teatral à análise do processo criativo
}

\author{
ANA CLARA SANTOS
}

Le théâtre est ailleurs. Il est dans la vie même qui anime la scène et qui fait qu'année après année, spectacle après spectacle, le théâtre ne cesse de se renouveler sans qu'aucune étude n'arrive à le figer ni même à en découvrir les lois fondamentales.

JOSETTE FÉRAL

A metodologia dos estudos de genética recentemente aplicada à arte teatral assenta sobretudo na preocupação em estabelecer pontes entre a análise teórica, semiológica e dramatúrgica e a análise dos processos criativos que estão na origem da prática do teatro (Lucet, Proust, Lemonnier-Texier, 2017; Grésillon, Mervant-Roux, Budor, 2010). Do estudo da passagem do texto à cena concretizada, sobretudo, através da abordagem semiológica dos anos 70 e 80, ao estudo dos processos de criação de um espectáculo, a distância é enorme. Sabemos que a prática teatral se inscreve numa prática social e que certos elementos do contexto estético, cultural, socioeconómico e político condicionam tanto a sua concepção como a sua leitura e análise. No entanto, é preciso ir mais longe e encarar este fenómeno artístico na sua complexidade, desde o momento em que se inicia a sua concepção até ao processo que culmina com a sua realização e apresentação junto do público.

A obra teatral, efémera por excelência, encerra em si um ciclo de construção artística cujo produto se torna visível no momento da sua representação. As etapas que conduziram à sua representação ficam arquivadas na memória artística dos seus intervenientes e, quando muito, em registos áudio, vídeo ou fotográfico, armazenados nos seus arquivos privados. É certo que, cada vez mais, as companhias tendem a produzir o seu próprio material de arquivo e de registo sobre as suas produções artísticas. Esta tendência é também uma repercussão da nova viragem da arte teatral contemporânea, assente, por vezes, na desconstrução do próprio processo criativo da cena em permanente work in progress (Féral, 2013). 
À crítica, pouco tem interessado o trabalho que precede a representação e que está na origem da criação artística. Às companhias teatrais, pouco tem interessado divulgar o seu trabalho submerso por trás dessa linha visível do espectáculo. A ausência de ferramentas e meios adequados de reflexão sobre o processo de criação artística, nomeadamente da arte teatral, não permitiu até hoje juntar, em Portugal, estes dois campos culturais (Bourdieu, 1992).

Nas últimas três décadas, os estudos desenvolvidos no domínio cultural anglófono e francófono fizeram emergir novos campos de investigação na área teatral como os chamados rehearsal studies (McAuley, 1998, 2012; Mitter, 1992) e os performance studies (Schechner, 2006). Ao aplicar métodos da análise etnográfica ao estudo do processo criativo nos ensaios de teatro, Gay McAuley desenvolveu, nos anos 90, um trabalho pioneiro na área que viria a legitimar a prática de certos princípios dos estudos de genética na área dos estudos teatrais. No entanto, como refere num estudo recente, apesar do interesse e dos avanços nessa área, as questões metodológicas ainda se mantêm, sendo necessário reunir esforços para melhorar procedimentos, instrumentos e ferramentas de estudo e análise desse processo:

\begin{abstract}
[...] as I observed more and more rehearsals it became clear that the critical apparatus provided by theatre studies (historiography, semiotics, text and performance analysis) was insufficient when attempting to deal with complex interpersonal relations, work practices and the collective creative process involved in rehearsal. (McAuley, 2012: 4)
\end{abstract}

Tais avanços na investigação teatral permitem considerar a peça de teatro não tanto na sua efemeridade do momento de curta duração que representa a sua representação em cena (o espectáculo em si), mas inscrita sobretudo num processo de criação constante e mutante resultante do gesto criador de uma equipa de artistas responsável pelas escolhas, processos e realizações, avanços e recuos da gestação da obra e do espectáculo. Esses avanços materializam-se num conhecimento mais aprofundado da criação teatral vista à luz da sua composição interna (e intima!) conducentes a um questionamento sobre a forma como os artistas inventam os seus processos, como operam as suas escolhas, como contornam alguns impasses e imprevistos, e como, nesse movimento de vaivém entre construção e desconstrução, registam, armazenam e conservam as marcas, tonalidades e ritmos do gesto criador. É na edificação 
dessa partitura teatral, íntima de um grupo artístico e alheia ao olhar do espectador e do público, que assentam técnicas e movimentos que caracterizam métodos e processos específicos de uma escrita em devir e de uma criação artística em construção.

Nesse sentido, torna-se emergente tornar visíveis os métodos utilizados pelos fazedores de teatro e dar prioridade aos estudos da teoria da produção artística, na qual o fenómeno é visto como processo e não apenas como produto. Assim, será possível consolidar a abertura do campo epistemológico de forma a integrar o estudo do processo criativo na análise do fenómeno artístico susceptível de contemplar, na sua reflexão, as experimentações, as escolhas técnicas, artísticas e estéticas.

Longos avanços e novos caminhos poderão ser desbravados graças à investigação na área da genética teatral em Portugal, envolta em novos desafios derivados da essência do movimento, intangível, do processo criativo e da representação teatral, tendo por matéria essencial o corpo do actor, a voz do encenador e as linguagens técnica, artística e estética aplicadas à especificidade do palco.

E disso pretende este Dossiê Temático dar conta de forma inédita, uma vez que se dá a palavra a artistas que ousam falar sobre as suas experimentações em palco - Alexandre Pieroni Calado - e a críticos e investigadores que procuram acompanhar procedimentos de processos criativos de algumas companhias de teatro no Brasil e em Portugal (Maria Clara Ferrer sobre o Teatro da Vertigem e Juarez Guimarães Dias sobre $\mathrm{O}$ Bando) ou ainda de certas práticas teatrais (a rescrita cénica da ópera King Priam, de Michael Kemp Tippett, no estudo de Ana Rita Figueira) e editoriais (a edição de Fausto, de Fernando Pessoa, por Carlos Pittella). 


\section{REFERÊNCIAS BIBLIOGRÁFICAS}

BOURDIEU, Pierre (1992), Les règles de l'art, Paris, Seuil.

FÉRAL, Josette (2013), «A Fabricação do Teatro: questões e paradoxos», Revista Brasileira Estudos Presença, Porto Alegre, 3 (2), maio/agosto, pp. 566-81. Disponível em: http://www.seer.ufrgs.br/presenca.

GrÉSILlon, Almuth, MERVANT-Roux, Marie-Madeleine e Budor, Dominique (2010), Genèses Théâtrales, Paris, CNRS Éditions.

LUCET, Sophie, PROUST, Sophie e LEMONNIER-TEXIER, Delphine (2017), Mémoire(s) et création dans les arts du spectacle, Rennes, Presses Universitaires de Rennes (no prelo).

MCAUlEy, Gay (1998), «Towards an Ethnography of Rehearsal», New Theatre Quarterly, Cambridge University Press, 53 , pp. $75^{-85}$.

- (2012) Not Magic but Work: An Ethnographic Account of a Rehearsal Process, Manchester, Manchester University Press.

MITTER, Shommit (1992), Systems of Rehearsal: Stanislavky, Brecht, Grotowski and Brook, Londres, Routledge.

SCHECHNER, Richard (2006), Performance Studies: An Introduction, Nova Iorque e Londres, Routledge. 